\title{
PENGARUH SUPLEMENTASI PROBIOTIK BAKTERI ASAM LAKTAT TERHADAP HISTOMORFOLOGI USUS DAN PERFORMAN PUYUH JANTAN
}

\section{EFFECTS SUPPLEMENTATION OF LACTIC ACID BACTERIA PROBIOTIC ON INTESTINAL HISTOMORPHOLOGY AND PERFORMANCE OF MALE QUAIL}

\author{
Sapta Chandra Marnadi Hidayat ${ }^{1 *}$, Sri Harimurti ${ }^{2}$, dan Lies Mira Yusiati $^{2}$ \\ ${ }^{1}$ PT. Mensana Aneka Satwa, Divisi Obat Hewan, Blitar, 66126 \\ ${ }^{2}$ Fakultas Peternakan, Universitas Gadjah Mada, Yogyakarta, 55281
}

Submitted: 24 December 2015, Accepted: 17 May 2016

\section{INTISARI}

Penelitian ini bertujuan untuk mengetahui pengaruh suplementasi probiotik bakteri asam laktat (BAL) terhadap histomorfologi usus dan performan pada puyuh jantan. Probiotik BAL indigenous yang digunakan terdiri dari campuran tiga strain BAL yaitu Lactobacillus murinus, Streptococcus thermophilus, dan Pediococcus acidilactici. Sebanyak 96 ekor day old quail (DOQ) puyuh jantan secara acak dibagi dalam empat kelompok suplementasi probiotik BAL dan dipelihara selama 42 hari. Suplementasi probiotik BAL via oral yaitu $0(\mathrm{P} 0), 10^{7}(\mathrm{P} 1), 10^{8}(\mathrm{P} 2)$, dan $10^{9}(\mathrm{P} 3) \mathrm{CFU} / \mathrm{mL} / \mathrm{ekor} / \mathrm{hari}$. Data penelitian dianalisis dengan analisis variansi RAL pola searah dilanjutkan dengan uji beda mean Duncan's New Multiple Range Test. Hasil penelitian menunjukkan bahwa probiotik BAL berpengaruh nyata terhadap morfologi usus, pertambahan bobot badan, dan konversi pakan $(\mathrm{P}<0,05)$. Panjang vili usus beruturut-turut adalah $288,45 \pm 8,18,322,72 \pm 1,84,324,82 \pm 2,06$, dan $390,80 \pm 13,24(\mu \mathrm{m})$. Lebar villi usus berturut-turut adalah $112,82 \pm 2,35,138,62 \pm 2,35,162,57 \pm 17,15$ dan $130,72 \pm 13,45(\mu \mathrm{m})$. Kedalaman kripta usus berturut-turut adalah $61,25 \pm 1,49,72,50 \pm 6,25,69,85 \pm 4,55$, dan $69,05 \pm 4,57(\mu \mathrm{m})$. Konsumsi pakan tidak menunjukkan perbedaan akan tetapi menghasilkan pertambahan bobot badan yang berbeda berturut-turut adalah $102,85 \pm 4,72,109,20 \pm 4,13,115,07 \pm 7,61$, dan $118,75 \pm 2,54$ (g). Konversi pakan berturut-turut adalah $4,30 \pm 0,43,4,26 \pm 0,17,3,91 \pm 0,30$, dan 3,79 $\pm 0,27$. Kesimpulan penelitian ini menunjukkan bahwa suplementasi probiotik BAL sebesar $10^{9} \mathrm{CFU} / \mathrm{mL} /$ ekor/hari menunjukkan hasil yang terbaik.

(Kata kunci: Histomorfologi, Performan, Probiotik BAL, Puyuh jantan)

\section{ABSTRACT}

The present study was conducted to investigate the effects of lactic acid bacteria (LAB) probiotics supplementation on intestinal histomorpholgy and performance of male quail. The LAB probiotics supplement contained of three strains, those are Lactobacillus murinus, Streptococcus thermophilus, and Pediococcus acidilactici. A total of 96 day-old male quails (DOQ) were randomly divided into four groups of $\angle A B$ probiotic supplementation reared for 42 days. Oral supplementation of $L A B$ probiotic were $0(P 0), 10^{7}$

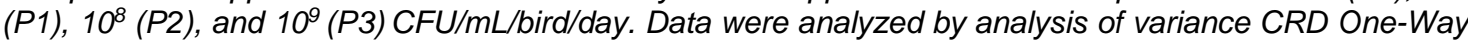
Anova continued with Duncan's New Multiple Range Test. The results showed that LAB probiotic treatment affected on the intestinal morphology, body weight gain, and feed conversion of male quail $(P<0.05)$. Height of intestinal villi were $288.45 \pm 8.18,322.72 \pm 1.84,324.82 \pm 2.06$, and $390.80 \pm 13.24(\mu \mathrm{m})$ respectively. Width of intestinal villi were $112.82 \pm 2.35,138.62 \pm 2.35,162.57 \pm 17.15$ and $130.72 \pm 13.45(\mu \mathrm{m})$ respectively. Depth of intestinal crypts were $61.25 \pm 1.49,72.50 \pm 6.25,69.85 \pm 4.55$, and $69.05 \pm 4.57(\mu \mathrm{m})$ respectively. Feed intake were not different, but resulted difference body weight gain, which were 102.85 $\pm 4.72,109.20 \pm 4.13$, $115.07 \pm 7.61$, and $118.75 \pm 2.54(\mathrm{~g})$, respectively. Feed conversion were $4.30 \pm 0.43,4.26 \pm 0.17,3.91 \pm 0.30$, and $3.79 \pm 0.27$, respectively. This study indicated that supplementation of $10^{9} \mathrm{CFU} / \mathrm{mL} / \mathrm{bird} /$ day of $L A B$ probiotics showed the best result.

(Key words: Histomorphology, Male quail, Performance, Probiotics LAB)

\footnotetext{
*Korespondensi (corresponding author):

Telp. +6285649174539

E-mail: chandrafapetugm@gmail.com
} 


\section{Pendahuluan}

Penggunaan antibiotik terutama sebagai pemacu pertumbuhan atau animal growth promoters (AGP) untuk semua ternak, termasuk pemberiannya pada unggas, telah dilarang di negara Uni Eropa sejak awal tahun 2006. Larangan penggunaan antibiotik sangat terkait dengan keamanan pangan dan kesehatan masyarakat, karena pemakaian antibiotik secara terus-menerus dapat menimbulkan residu pada daging dan telur unggas serta membentuk bakteri yang tahan terhadap antibiotik (Donoghue, 2003; Castanon, 2007). Salah satu pilihan alternatif sebagai pengganti antibiotik adalah suplementasi probiotik. Hal ini dikarenakan suplementasi probiotik dinilai lebih aman untuk produk peternakan yang dihasilkan dan bermanfaat dalam menjaga kesehatan usus inang.

Probiotik didefinisikan ulang sebagai kultur tunggal atau campuran mikrobia hidup yang apabila diaplikasikan dengan dosis yang memadai memberikan efek menguntungkan pada inang karena kemampuannya dalam menjaga kesehatan saluran digesti (Antoine, 2010). Pemberian probiotik sejak awal kehidupan membantu unggas lebih cepat dalam membentuk keseimbangan mikroflora usus (Kabir, 2009). Kondisi mikroflora yang seimbang menyebabkan terbentuknya sistem pertahanan yang baik pada lumen usus (Jeppsson et al., 2004). Probiotik juga memilki kemampuan untuk memodulasi karakteristik fisiologi pada saluran digesti seperti imunitas mukosa, mucosal trophicity, dan permeabilitas usus (Fioramonti et al., 2003).

Suplementasi probiotik dapat memicu produksi short chain fatty acids (SCFA) atau lebih dikenal dengan asam lemak rantai pendek. Asam butirat merupakan SCFA yang berperan penting dalam proses proliferasi sel epitel usus. Peningkatan produksi asam butirat membantu dalam perluasan bidang absorbsi pada lumen usus sehingga absorbsi nutrien diharapkan menjadi lebih optimal (Ichikawa et al., 1999; Ohashi dan Ushida, 2009). Produksi SCFA memerlukan kerjasama antara bakteri penghasil asam organik dengan bakteri lain yang ada dalam usus inang melalui mekanisme yang disebut dengan cross-feeding mechanism (Van Immerseel et al., 2006). Bakteri tersebut menghidrolisis karbohidrat yang tidak tercerna menjadi monosakarida melalui fermentasi anaerobik dalam usus.
Monosakarida yang terbentuk kemudian dikonversi menjadi phosphoenol piruvat (PEP) melalui jalur Embden-Meyerhof-Parnas (glikolisis) dan pentosa-fosfat, selanjutnya diubah menjadi asam-asam organik (Besten et al., 2013). Asam lemak rantai pendek (SCFA) yang terabsorbsi merupakan sumber energi utama bagi enterocytes, sehingga dapat membantu dalam memenuhi kebutuhan energi pada inang (Resta, 2009).

Berdasarkan uraian tentang penggunaan probiotik pada unggas diatas maka, tujuan dari penelitian ini untuk mengetahui pengaruh suplementasi probiotik BAL terhadap histomorfologi usus dan performan produksi pada puyuh jantan.

\section{Materi dan Metode}

Penelitian ini dilakukan di Laboratorium IImu Ternak Unggas Fakultas Peternakan dan Laboratorium Mikrobiologi Fakultas Kedokteran Hewan, Universitas Gadjah Mada, Yogyakarta.

\section{Materi}

Alat. Penelitan ini menggunakan kandang koloni sebanyak 16 unit beralas kawat yang dilengkapi tempat penampungan ekskreta, masing-masing unit berukuran $35 \mathrm{x}$ 28 x $24 \mathrm{~cm}$. Alat yang digunakan untuk menimbang pakan dan puyuh adalah timbangan digital merk Camry kapasitas $5 \mathrm{~kg}$ dengan kepekaan 0,05 g. Alat yang digunakan untuk pemberian BAL via mulut meliputi masker, alkohol steril 70\%, dan disposable syringe $1 \mathrm{~mL}$ merk OneMed.

Bahan. Probiotik BAL indigenous yang digunakan adalah kultur bakteri probiotik diperoleh dari Prof. Sri Harimurti yang di dalamnya mengandung campuran tiga strain BAL yaitu Lactobacillus murinus (Ar3), Streptococcus thermophilus (Kp2), dan Pediococcus acidilactici (Kd6). BAL tersebut berasal dari saluran pencernaan ayam kampung asli Indonesia. Bahan pakan yang digunakan dalam menyusun ransum puyuh meliputi jagung kuning, bekatul, SBM, PMM, full-fat, MBM, minyak sawit, dan premix.

\section{Metode}

Sebanyak 96 ekor puyuh jantan berumur dua minggu dibagi secara acak dalam empat kelompok level suplementasi probiotik BAL. Masing-masing kelompok perlakuan diulang sebanyak empat kali dengan setiap ulangan terdiri dari 6 ekor 
puyuh. Kelompok perlakuan pada penelitian adalah sebagai berikut:

P0: Tanpa suplementasi probiotik BAL

P1: Suplementasi probiotik BAL $10^{7}$ CFU/mL/ekor/hari

P2: Suplementasi probiotik BAL $10^{8}$ CFU/mL/ekor/hari

P3: Suplementasi probiotik BAL $10^{9}$ CFU/mL/ekor/hari

Selama 42 hari pemeliharaan, puyuh diberi pakan serasi untuk puyuh bebas antibiotik dengan CP 24,03\% dan ME 2908,05 $\mathrm{kcal} / \mathrm{kg}$. Pemberian pakan dan air minum secara ad libitum. Suplementasi probiotik BAL melalui tetes mulut sebanyak $1 \mathrm{~mL}$ diberikan mulai hari ke 14-42 kepada setiap puyuh pada semua perlakuan yang dilakukan pada pagi hari. Kelompok perlakuan tanpa suplementasi probiotik BAL (PO) diberikan aquades $1 \mathrm{~mL}$ agar mendapat cekaman yang sama. Puyuh dipotong satu ekor pada setiap ulangan pada hari ke 42 kemudian diambil sampel usus halus pada segmen duodenum digunakan untuk uji histologis. Pembuatan preparat histologis dari sampel usus halus sesuai metode haematoxylin-eosin. Pengamatan preparat histologis menggunakan mikroskop Olympus BX 51 perbesaran 40 kali. Kedalaman kripta usus diukur dengan menggunakan software Opti Lab Image Raster. Konsumsi pakan dihitung dari selisih bobot pakan yang diberikan pada puyuh dengan sisa pakan selama penelitian dari masing-masing kelompok perlakuan. Pertambahan bobot badan dihitung dari selisih bobot badan puyuh pada akhir penelitian dengan bobot badan awal pada masing-masing kelompok perlakuan. Konversi pakan diperoleh dari hasil pembagian antara jumlah pakan yang dikonsumsi dengan pertambahan bobot badan puyuh dalam satuan bobot dan waktu yang sama.

Analisis data. Rancangan percobaan yang digunakan dalam penelitian adalah Rancangan Acak Lengkap (RAL) pola searah. Data dianalisis dengan analisis variansi dan dilanjutkan dengan uji beda mean Duncan's New Multiple Range Test.

\section{Hasil dan Pembahasan}

Hasil penelitian pengaruh suplementasi probiotik bakteri asam laktat (BAL) sebesar 0; $10^{7} ; 10^{8}$ dan $10^{9} \mathrm{CFU} / \mathrm{mL} /$ ekor/hari melaui tetes mulut terhadap histomorfologi usus dan performan pada puyuh jantan disajikan pada Tabel 1 dan 2.

\section{Tinggi vili, lebar villi, dan kedalaman kripta usus}

Suplementasi probiotik BAL berpengaruh nyata terhadap tinggi villi, lebar villi, dan kedalaman kripta usus puyuh jantan $(P<0,05)$. Rerata tinggi villi, lebar villi, dan kedalaman kripta usus yang disuplementasi probiotik BAL khususnya level $10^{8}$ dan $10^{9}$ CFU/mL/ekor/hari secara nyata lebih tinggi dibandingkan dengan kontrol (Tabel 1). Histomorfologi usus dapat mencerminkan status kesehatan pada hewan ternak. Bertambahnya tinggi villi dan kedalaman kripta pada duodenum merupakan indikasi status kesehatan yang baik pada ternak. Probiotik memicu produksi asam lemak rantai pendek (SCFA) yang berperan dalam proses proliferasi sel epitel usus (Ichikawa et al., 1999). Asam lemak rantai pendek (SCFA) khususnya butirat yang merupakan komponen fospolipid membran sel diproduksi oleh bakteri Bifidobacteria dan Lactobacilli melalui proses fermentasi anaerob dalam usus (Besten et al., 2013; Resta, 2009).

Tabel 1. Pengaruh suplementasi probiotik BAL terhadap histomorfologi usus puyuh jantan selama pemeliharaan 42 hari

(effect of $L A B$ probiotics supplementation on intestinal histomorphology male quail during 42 days maintenance)

\begin{tabular}{|c|c|c|c|c|}
\hline \multirow[t]{2}{*}{ Variabel (variable) } & \multicolumn{4}{|c|}{$\begin{array}{c}\text { Level probiotik BAL (CFU/mL/ekor/hari) (level of LAB } \\
\text { probiotics (CFU/mL/bird/day)) }\end{array}$} \\
\hline & $0(\mathrm{PO})$ & $10^{7}(\mathrm{P} 1)$ & $10^{8}(\mathrm{P} 2)$ & $10^{9}(\mathrm{P} 3)$ \\
\hline Tinggi villi $(\mu \mathrm{m})($ villi height $(\mu \mathrm{m}))$ & $288,45 \pm 8,18^{a}$ & $322,72 \pm 1,84^{b}$ & $324,82 \pm 2,06^{b}$ & $390,80 \pm 13,24^{c}$ \\
\hline Lebar villi $(\mu \mathrm{m})$ (villi width $(\mu \mathrm{m}))$ & $112,82 \pm 2,35^{a}$ & $138,62 \pm 2,35^{b}$ & $162,57 \pm 17,15^{c}$ & $130,72 \pm 13,45^{b}$ \\
\hline $\begin{array}{l}\text { Kedalaman kripta }(\mu \mathrm{m}) \text { (crypts } \\
\text { depth }(\mu \mathrm{m}) \text { ) }\end{array}$ & $61,25 \pm 1,49^{a}$ & $72,50 \pm 6,25^{b}$ & $69,85 \pm 4,55^{b}$ & $69,05 \pm 4,57^{b}$ \\
\hline
\end{tabular}


Tabel 2. Pengaruh suplementasi probiotik BAL terhadap performan puyuh jantan selama pemeliharaan 42 hari

(effect of $L A B$ probiotics supplementation on male quail performance during 42 days maintenance)

\begin{tabular}{lcccc}
\hline \hline \multirow{2}{*}{ Variabel (variable) } & \multicolumn{3}{c}{ Level probiotik BAL (CFU/mL/ekor/hari) (level of LAB } \\
probiotics (CFU/mL/bird/day))
\end{tabular}

Pembentukan asam butirat ini melalui poses yang dinamakan cross-feeding mechanism (Van Immerseel et al., 2006). Probiotik BAL yang digunakan dalam penelitian ini telah dibuktikan oleh Harimurti et al. (2014) mampu memproduksi butirat sebesar 0,033 $\mathrm{mmol} / \mathrm{L}$ dalam saluran digesti puyuh.

Absorbsi nutrien akan menjadi lebih efisien jika bidang absorsi lebih lebar dan luas. Selain itu struktur villi dalam usus juga berpengaruh terhadap laju pakan. Struktur villi zig-zag akan lebih baik karena laju pakan menjadi lebih lama sehingga absorbsi nutrien pakan menjadi lebih maksimal (Pelicano et al., 2005). Sel epitel dan entrosit baru diproduksi oleh kripta yang kemudian bermigrasi menuju ke villi (Abdel-Rahem et al., 2012; Gomez et al., 2012; Peric et al., 2010).

Permukaan saluran usus dilapisi oleh viscoelastic mucous gel yang berperan sebagai sistem pertahanan alami dan juga membantu dalam absorbsi nutrien (Herich dan Levkut, 2002). Probiotik memiliki kemampuan untuk berikatan dengan lapisan mukosa tersebut. Probiotik yang telah beraderensi pada sel epitel usus kemudian berkoloni dan terjadi proses fermentasi menghasilkan berbagai macam produk yang bermanfaat dalam meningkatkan kesehatan saluran digesti inang (Fioramonti et al., 2003; Ghosh et al., 2007). Antoine (2010) melaporkan bahwa pada dinding usus terdapat sel Goblet yang berfungsi untuk mensekresikan mukosa dan sel Paneth yang berperan dalam mensekresikan zat antimikrobia (defensin).

\section{Konsumsi pakan}

Suplementasi probiotik BAL tidak berpengaruh nyata terhadap konsumsi pakan.
Namun demikian, dengan konsumsi pakan yang relatif sama ternyata menghasilkan pertambahan bobot badan yang berbeda (Tabel 2). Puyuh yang disuplementasi probiotik BAL menghasilkan pertambahan bobot badan yang lebih baik dibandingkan kontrol. Hal ini menunjukkan terjadinya efisiensi pakan pada puyuh. Probiotik BAL yang digunakan dalam penelitian ini dibuktikan oleh Harimurti dan Widodo (2014) dapat menghasilkan asam lemak rantai pendek (SCFA) yang merupakan asam organik melalui proses cross-feeding mechanism. Diduga efisiensi pakan terjadi akibat asam organik yang dihasilkan dapat berkontribusi dalam memenuhi kebutuhan energi untuk pemeliharaan dan juga digunakan untuk proses katabolisme. Meskipun demikian dari total energi SCFA yang dihasilkan tersebut hanya $25 \%$ saja yang dapat dimanfaatkan oleh unggas (Mroz, 2005; Van Immerseel et al., 2006; Roto et al., 2015).

\section{Pertambahan bobot badan}

Suplementasi probiotik BAL berpengaruh terhadap pertambahan bobot badan pada puyuh jantan $(P<0,05)$. Rerata bobot badan puyuh jantan yang disuplementasi probiotik BAL khususnya level $10^{8}$ dan $10^{9} \mathrm{CFU} / \mathrm{mL} /$ ekor/hari secara nyata lebih tinggi dibandingkan dengan kontrol (Tabel 2). Diduga probiotik BAL bekerja dalam meningkatkan pertambahan bobot badan pada puyuh jantan. Hal ini disebabkan bakteri probiotik meningkatkan produksi enzim pencernaan. Jin et al. (2000) menyatakan bahwa suplementasi probiotik Lactobacillus mampu meningkatkan aktivitas enzim lipolitik, proteolitik, dan amilolitik pada usus halus. Namun enzim amilolitik yang lebih ditingkatkan aktivitasnya oleh probiotik. 
Peningkatan aktivitas enzim pencernaan kemungkinan juga disebabkan oleh probiotik BAL dalam memperbaiki pertumbuhan sel epitel usus dimana pada bagian tersebut mensekresikan enzim-enzim pencernaan. Oleh sebab itu pakan yang dikonsumsi dapat dicerna dan diabsorbsi secara optimal sehingga kebutuhan nutrien akan terpenuhi secara baik. Selain itu probiotik dapat meningkatkan kelarutan mineral khususnya kalsium akibat produksi asam lemak rantai pendek (SCFA) dan sintesis vitamin $\mathrm{B}_{12}$ dan $\mathrm{K}$ yang penting bagi tubuh (Ahrens et al., 2007; Resta, 2009).

\section{Konversi pakan}

Suplementasi probiotik BAL berpengaruh terhadap pertambahan bobot badan pada puyuh jantan $(P<0,05)$. Rerata konversi pakan puyuh jantan yang disuplementasi probiotik BAL khususnya level $10^{9} \mathrm{CFU} / \mathrm{mL} / \mathrm{ekor} / \mathrm{hari}$ secara nyata lebih rendah dibandingkan dengan kontrol (Tabel 2). Hal ini terjadi karena adanya perbaikan histomorfologi usus akibat suplementasi probiotik BAL sehingga bidang absorbsi nutrien menjadi lebih luas (Tabel 1). Tingkat pertumbuhan dan efisiensi pakan dipengaruhi oleh kemampuan ternak untuk mengkonsumsi, mencerna, menyerap dan memetabolisme nutrien pakan (Scott, 2005). Perbaikan FCR dapat terjadi akibat adanya penurunan lemak tubuh, peningkatan metabolisme energi pakan, dan peningkatan ketersediaan net energi dan protein untuk deposisi otot. Respon positif dari efek tersebut adalah perbaikan efisiensi pakan yang terlihat dengan tercapainya nilai FCR yang rendah (Pym, 2005). Probiotik membantu dalam membentuk keseimbangan mikrobia di dalam saluran pencernaan inang yang selanjutnya berperan untuk menjaga kesehatan inang (Vali, 2009). Efek positif yang didapatkan dari terbentuknya keseimbangan mikroflora dalam saluran pencernaan adalah konsumsi pakan dan konversi pakan menjadi efisien (Arslan dan Saatci, 2004).

\section{Kesimpulan}

Berdasarkan penelitian yang telah dilakukan dapat diambil kesimpulan bahwa suplementasi probiotik BAL yang terdiri dari Lactobacillus murinus (Ar3), Streptococcus thermophilus (Kp2), dan Pediococcus

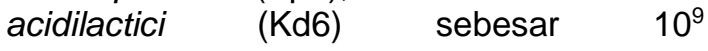

$\mathrm{CFU} / \mathrm{mL} /$ ekor/hari dapat meningkatkan performan tinggi villi, lebar villi, dan kedalaman kripta usus untuk memperluas bidang absorbsi nutrien sehingga menghasilkan pertambahan bobot badan dan konversi pakan yang lebih baik dibandingkan kontrol.

\section{Daftar Pustaka}

Abdel-Raheem, S. M., M. S. S. Abd-Allah and M. A. K. Hassanein. 2012. The effects of prebiotic, probiotic and synbiotic supplementation on intestinal microbial ecology and histomorphology of broiler chickens. IJAVMS 6: 277-289.

Ahrens, K. E. S., P. Ade, B. Marten, P. Weber, W. Timm, Y. Asil, C. C. Gluer, and J. Schrezenmeir. 2007. Prebiotics, probiotics, and synbiotics affect mineral absorption, bone mineral content, and bone structure. J. Nutr. 137: 838S8465 .

Antoine, J. M. 2010. Probiotics in the defence and metabolic balance of the organism Probiotics: beneficial factors of the defence system. The 3rd International Immunonutrition Workshop. Proceedings of the Nutr. Soc. 69: 429433.

Arslan, C. and M. Saatci. 2004. Effect of Probiotics admininstation either as feed additive or by drinking water on performance and blood parameters of japanesse quail. Arch. Geflugelk. 68: 160-163.

Besten, G. D., K. V. Eunen, A. K. Groen, K. Venema, D. J. Reijngoud, and B. M. Bakker. 2013. The role of short-chain fatty acids in the interplay between diet, gut microbiota, and host energy metabolism. J. Lipid Res. 54: 23252340.

Castanon, J. I. R. 2007. History of the use of antibiotic as growth promoters in European poultry feeds. J. Poult. Sci. 86: 2466-2471.

Donoghue, D. J. 2003. Antibiotic residues in poultry tissues and eggs: Human health concerns. J. Poult. Sci. 82: 618-621.

Fioramonti, J., V. Theodorou, and L. Bueno. 2003. Probiotics: what are they? What are their effects on gut physiology?. Best Practice \& Research Clinical Gastroenterology 17: 711-724. 
Gómez, S., M. L. Angeles, M. C. Mojica, and S. Jalukar. 2012. Combination of an enzymatically hydrolyzed yeast and yeast culture with a direct-fed microbal in the feeds of broiler chickens. AsianAust. J. Anim. Sci. 25: 665-673.

Ghosh, H. K., G. Halder, G. Samanta, S. K. Paul, and S. K. Pyne. 2007. Effect of dietary supplementation of organic acid and mannan oligosaccharide on the performance and gut health of Japanese Quail (Cortunix cortunix japonica). Asian J. Poult. Sci. 1: 1-7.

Harimurti, S., J. P. H. Sidadolog, Wihandoyo, T. Yuwanta, S. Sudaryati, H. Sasongko, dan B. Ariyadi. 2014. Dinamika probiotik indigenous bakteri asam laktat pada kinerja pertumbuhan, produksi asam lemak rantai pendek, dan total bakteri aderensi dalam usus puyuh jantan. Laporan Penelitian Hibah Penelitian Tematik Laboratorium, Fakultas Peternakan, Universitas Gadjah Mada, Yogyakarta.

Harimurti, S. and Widodo. 2014. Effect of indigenous probiotics lactic acid bacteria on performance, intestinal length and weight of internal organs of broiler chicken. ICOBM 2014 D-8.

Herich, R. and M. Levkut. 2002. Lactic acid bacteria, probiotics and immune system. Vet. Med. Czech. 47: 169-180.

Ichikawa, H., T. Kuroiwa, A. Inagaki, R. Shineha, T. Nishihira, S. Satomi, and T. Sakata. 1999. Probiotic bacteria stimulate gut epithelial cell proliferation in rat. Dig. Dis. Sci. 44: 2119-2123.

Jeppsson, B., P. Mongell, D. Adawi, and G. Molin. 2004. Bacterial translocation: impact of probiotics. Scandinavian J. Nutr. 48: 37-41.

Jin, L. Z., Y. W. Ho, N. Abdullah, and S. Jalaludin. 2000. Digestive and bacterial enzyme activities in broilers fed diets supplemented with lactobacillus cultures. Poult. Sci. 79: 886-891.

Kabir, S. M. L. 2009. The role of probiotics in the poultry industry. Int. J. Mol. Sci. 10: 3531-3546.
Mroz, Z. 2005. Organic Acids as Potential Alternatives to Antibiotic Growth Promoters for Pigs. Advances in Pork Production 16: 169.

Ohashi, Y. and K. Ushida. 2009. Healthbeneficial effects of probiotics: Its mode of action. J. Anim. Sci. 80: 361-371.

Pelicano, E. R. L., P. A. Souza, H. B. A. Souza, D. F. Figueiredo, M. M. Boiago, S. R. Carvalho, and V. F. Bordon. 2005. Intestinal mucosa development in broiler chickens fed natural growth promoters. Braz. J. Poult. Sci. 7: 221229.

Perić, L., N. Milošević, D. Zikić, S. Bjedov, D. Cvetković, S. Markov, M. Mohnl and T. Steiner. 2010. Effects of probiotic and phytogenic products on performance, gut morphology and cecal microflora of broiler chickens. Archiv. Tierzucht 53: 350-359.

Pym, R. A. E. 2005. Genetic aspects of food intake and food utilisation efficiency for growth in chickens. Aust. Poult. Sci. Symp. 17: 153-62.

Resta, S. C. 2009. Effects of Probiotics and Commensals on Intestinal Epithelial Physiology: Implications for Nutrient Handling. J. Physiol. 587: 4169-4174.

Roto, S. M., P. M. Rubinelli and S.C. Ricke. 2015. An introduction to the avian gut microbiota and the effects of yeastbased prebiotic-type compounds as potential feed additives. Front. Vet. Sci. 2: 28.

Scott, T. A. 2005. Variation in feed intake of broiler chickens. Recent Advances in Animal Nutrition in Australia 15: $237-$ 244.

Vali, N. 2009. Probiotic in quail nutrition: a review. Int. J. Mol. Sci. 8: 1218-1222.

Van Immerseel, J. Russel, M. Flythe, I. Gantois, L. Timbermont, F. Pasmans, F. Haesebrouck, and R. Ductalle. 2006. The use organic acids to combat salmonella in poultry: a mechanistic explanation of the efficacy. Avian pathol. 35: 182-188. 